\title{
DEVELOPING ESP SYLLABUS AND TEACHING MATERIALS FOR PORT BUSINESS EMPLOYEES
}

\author{
Rizqiliyah Issabella ${ }^{2}$
}

\begin{abstract}
This study is aimed to cater the needs of professionals of sea port business to enhance their English speaking proficiency. Due to their limited time to study, the design of the syllabus must focus on the materials they usually use in their daily operation. The syllabus and the materials were designed using ADDIE model which stands for Analyzing, Designing, Developing, Implementing and Evaluating. In the Analyzing stage, ten topics were needed in practicing their English. The program was designed for one term covering fifteen meetings for ninety minutes each. The syllabus and materials had been reviewed by the expert of the port business. The order of the materials presented was based on the scope, from the small to the broad ones. One material was tried out to a specific group of learners resembling the target group, and the learners showed positive remark on both of the materials and the delivery.
\end{abstract}

Keywords: ESP, Speaking, Developing materials.

\section{Introduction}

Port Business is one industry among others which need to use English in their daily operation, as supply and logistics chain are mostly done in this location. A good command of English is a key factor in promoting smooth operation with the multinational seafarers, and reducing the risk of accident through human factor. The corporates in charge of this

\footnotetext{
${ }^{2}$ The researcher is a graduate of Master Degree of English for Foreign Language, Widya Mandala Catholic University Surabaya. She is currently an English Language consultant and program designer of one of a state-owned enterprise in port business in Indonesia. She has been working in different field of ESP-EOP for approximately 12 years.
} 
process, called terminal operators, are aware of this issue and commit to improving their employees' competency in using the target language in a working environment. However, their limited time and energy availability hinders the intention, and it leads to the need of the simplified; work-focus oriented and practical English training in EOP domain.

Research on the existence and materials of EOP - English for Port was limited as this is a relatively new field. Studies in a similar field, Maritime English (Bocanegra-Valle, 2002; Gabrielli, 2015), are available although there were not many. Therefore, constructing a new syllabus and materials is the best option to suit the needs. The process involves specific components (Nunan, 1998) to meet the role based on the types chosen (Cunningsworth, 1995; Khranhke, 1987; Tomlinson, 2011). Therefore, this study attempts to design the syllabus and materials to cater to the needs of the corporate, as there is no specific material about English for Port Business, especially for the communicative approach in speaking and listening skills.

\section{Methods}

In this study, a Research and Development design was used since it was aimed to produce syllabus and materials relevant to the real-context use of Port Business activities specified into a model called ADDIE (Analysis, Design, Development, Implementation and Evaluation) (Aldobie, 2015; Damron, 2006; Graves, 2008). This study was presented in the design as follows: 


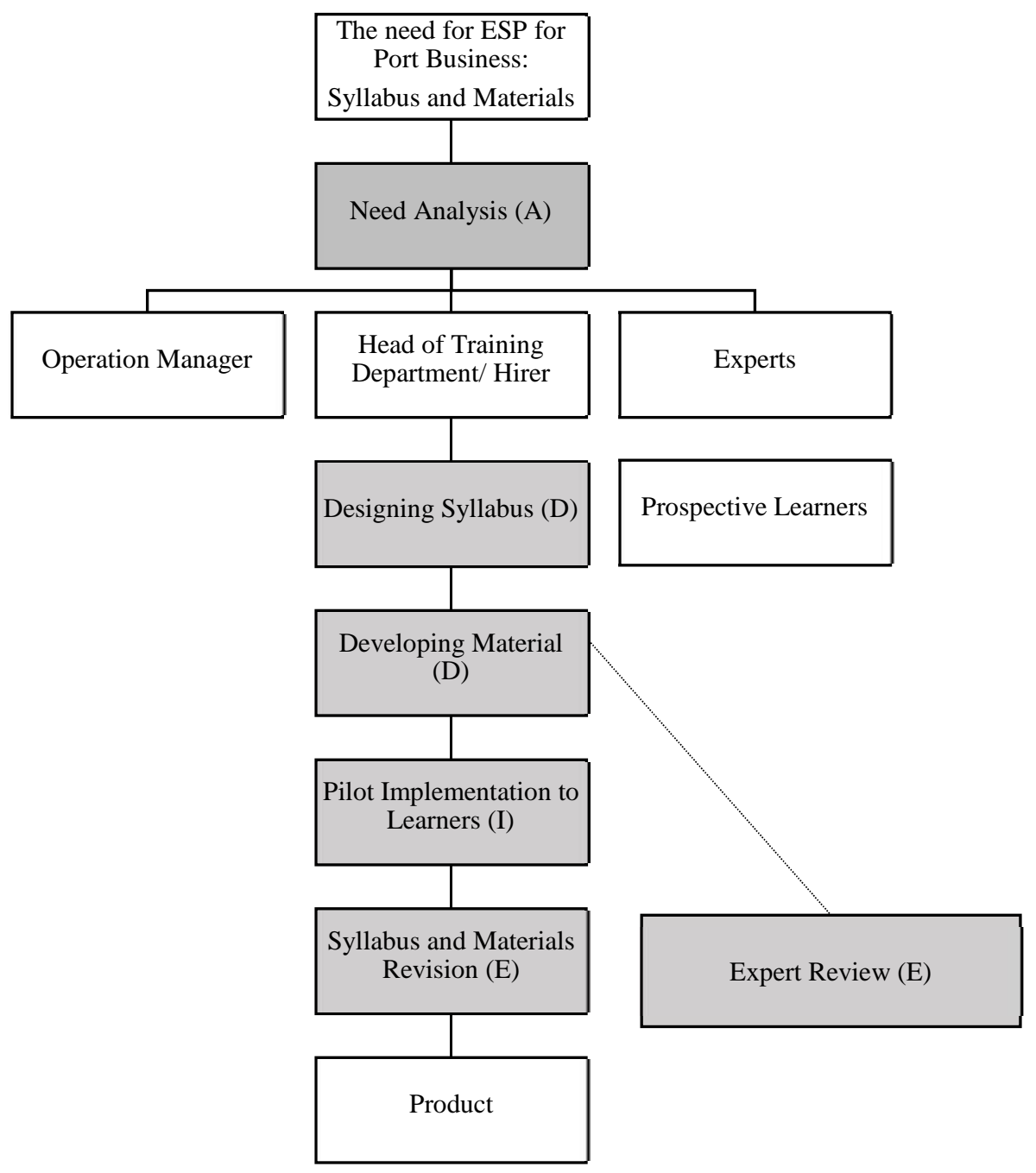

Figure 1. Design of Syllabus and Materials Development Method for English for Port Business

Need analysis will focus on the needs of the stakeholders, ranging from the sponsor, the subject specialist, and the prospective learners (Jordan, 2011; Tahir, 2011). The data obtained through the interview of the hirer and experts and the questionnaire for the potential learners were analyzed using a need-analysis addressing the Necessities, Lacks and 
Wants (Hutchinson and Waters, 1987). In-depth interview was used to get information related to the content subject. The first stage was addressed to the Head of Training Department to obtain information about the expectation from the programs, overall goal of lesson, the skill needed, the learners' background, including age, education, unit, and position (Appendix 1). Semi-structured interview was chosen as more information could be expected to be obtained during the interview. The interview was done during working hours in her office by appointment. The first interviewee then introduced the researcher to an Operation Manager and his team in order to obtain authentic information.

The second interview was conducted to the practitioners in operation namely Operation Manager and International Passenger Terminal Manager and his team in order to obtain information about the relevant topics and activities in using the target language in real-life context (Appendix 2). During the interview with the operation manager, site visit was simultaneously conducted in order to get clear ideas for the business process of the corporate. Those interviews was completed with gathering text/ internal documents, company profile, pictures, leaflet and other relevant authentic documents.

The data were collected, mapped, and presented in the form of table and later described and analyzed in words, phrases and sentences. These instruments had been tested in try-outs with the equivalent sources such as a lecturer representing the experts and the head of training department. Four people acted as learners and filled out the questionnaires. This pilot test was to measure the validity of the instruments as well as the predicted duration for each interview or questionnaire filling. The instruments were revised based on the response of the stakeholders involved in this pilot test.

The questionnaire was used in an attempt to see learners' preferred learning styles, the preference of materials and the expected materials to 
learn, motivation, interest and attitudes to teaching/learning methods, obstacle to learn, anxiety, concentration, and time constraint.

The samples were taken randomly, decided by the management to illustrate the future learners of this program. The prospective learners are the employees who were sponsored in their study, recruited after their graduation from senior high school and given scholarship for their diploma and bachelor degree in business administration. They are now recruited as the permanent employees who mostly work in operation division. Sixty questionnaires were distributed via Google form, and the learners responded within the specific time given. There was no face-to-face contact with the learners during this questionnaire distribution. In addition, interviews were conducted to selected learners.

The data of The Necessities were summarized from the perspective of the management and operation team of PT. Pelabuhan Indonesia III (Persero) by interview, while the Wants were taken from the learners' views by questionnaires. Therefore, the Lacks is discovered and established in the syllabus.

Having had the result of the need analysis from the steps above, the study proceeded to designing the syllabus. The syllabus identity was obtained through determining the course prerequisites, age and course length (Brown, 2000; Damron et al., 2006). Afterward, the goal of the units was determined, and cascaded into objectives of each unit. Afterward, course content is delivered into the topics, objectives, outcomes, language function, learning model, media and assessment( Richard \& Lockhart, 1994). The syllabus was designed for 1 term or 15 meetings for intermediate level of learners' English competency determined by placement test. The syllabus was then reviewed by the subject experts to get the feedback.

The syllabus revised after the experts review was the main source of the development of the materials. The materials comprised of 10 units with various activities accommodating the communication target of the 
learners. Besides, the equipment and tools, class setting, and media were stated. Consulting with experts was also a significant part in this development, and revising the materials was the end product of this stage.

The implementation stage is a try-out to see the effectiveness in the real teaching-learning context. The selected group of learners who were similar with the target group assisted as learners in this try out for Unit One Meeting One. The researcher acted as the teacher. The duration of the tryout was 90 minutes, the same with the real-class duration. The flaws were carefully recorded and noted by the teacher for the future revision, and learners' feedback is necessary to get their perspective (Ellis, 1987; Graves, 2008; Tomlinson ,1998).

\section{Results of Development and Discussion of the Findings}

\section{Analyzing}

The needs analysis process resulted in the identification of Necessities, Wants and Lacks as summarized into table 1 :

Table 1 The analysis of necessities, wants and lacks

\begin{tabular}{|c|c|c|c|}
\hline Aspects & $\begin{array}{l}\text { Necessities } \\
\text { Hirer's } \\
\text { Need }\end{array}$ & $\begin{array}{c}\text { Wants } \\
\text { Learners' } \\
\text { Expectations }\end{array}$ & $\begin{array}{c}\text { Lacks } \\
\text { Subject } \\
\text { Expert's Views }\end{array}$ \\
\hline Skills & $\begin{array}{l}\text { - Speaking } \\
\text { - Formal } \\
\text { Presentation } \\
\text { - Public } \\
\text { Speaking } \\
\text { - Port business } \\
\text { terminologies }\end{array}$ & $\begin{array}{l}\text { - Practices on } \\
\text { speaking } \\
\text { - Practices on } \\
\text { formal } \\
\text { presentation } \\
\text { - Listening }\end{array}$ & $\begin{array}{l}\text { Fluency in } \\
\text { speaking about } \\
\text { activities in } \\
\text { port }\end{array}$ \\
\hline
\end{tabular}




\begin{tabular}{|c|c|c|}
\hline & $\bullet$ Millennial & $\bullet$ Time to \\
professionals & study : \\
Specific & $(22-35$ y.o $)$, & $07.30-09.00$ \\
Information & $\begin{array}{l}\text { operation and } \\
\text { non-operation } \\
\text { background }\end{array}$ & \\
\hline
\end{tabular}

The list of Necessities was drawn from the analysis of interview of the Head of Training Department and the subject expert in the Port business, the Wants was from the prospective learners drawn from the questionnaires, and the Lacks was from the subject expert in Port Business, by interview.

\section{Designing}

The most prominent materials that learners must master through the implementation of current curriculum is the port business process all focused on spoken skills. Alongside that main material, there are also materials about heavy equipment used in the port, the terminal profile, company profile and comparison of Tanjung Perak port with other overseas ports. These topics were sequenced and taught to learners systematically based on the scope of the materials, from the narrow to the wider ones. The frequency of meetings was determined by the rank of priority of each topic mentioned above. The topics are presented into the sequence as shown in Table 2:

Table 2. Topics Sequence

\begin{tabular}{|c|l|}
\hline No & Topic \\
\hline 1. & Business process \\
\hline
\end{tabular}




\begin{tabular}{|c|l|}
\hline No & \multicolumn{1}{|c|}{ Topic } \\
\hline 2. & Services of Pelindo III \\
\hline 3. & Vessels \\
\hline 4. & Heavy Equipment \\
\hline 5. & Terminals of Pelindo III \\
\hline 6. & Stakeholders \\
\hline 7. & Pelindo 3 Group \\
\hline 8. & Passenger Terminal \\
\hline 9. & P3 Terminal vs. International Overseas Terminal \\
\hline 10. & Field Trip 1 : GSN \\
\hline
\end{tabular}

The syllabus main focus is to improve the learners' speaking and listening skills (80\%), complimented with a smaller portion of reading and writing practice $(20 \%)$. The syllabus will employ a learner-centered approach as this will provide learners with more opportunities to practice their speaking skill. The teachers will only give introduction, conclusion, as well as oral input whenever the learners need correction. The learners, on the other side, will have to conduct group discussion and presentations according to the theme given.

As the syllabus design and the materials proposed are highly specific, certain ability level of the learners is required. The proposed 
learners for English for Port Business program are Intermediate, as they have sufficient language skills and vocabulary mastery in order to actively participate in class. Therefore, a placement test was created to select the learners.

The class was suggested to be held in the morning at 7.00 a.m. until 8 am (during working hours). The length of each term will be 15 meetings ( 2 meetings/week for 2 months) for each 90 minutes per meeting. Maximum 15 learners are suggested in this class.

In order to effectively monitor the progress of the learners, formative assessment is employed in every meeting basis. The learners are required to have a specific production as stated in the syllabus and record their voice, or voices when they work in pair and in group. The rubric is provided to guide the teacher in scoring the production. Each topic contributes $10 \%$ of the total score, while the final presentation takes $20 \%$.

\section{Developing materials}

The syllabus is set to be the main reference in developing the materials. There are 10 topics covered into 14 meetings, and the last meeting is for final project presentation. Each topic is cascaded into the materials, the activity and the feedback model. The materials are taken from the interview results, the corporate official websites, the corporate annual report, the corporate guidebook, the site visit field notes and many other external sources based on the criteria of good materials (Cuningsworth, 1995; Tomlinson, 1998)

\section{Implementing the syllabus/ materials}

The implementation was carried out with a selected group of learners ( 8 people) to assess whether the syllabus and materials were relevant with the target group. The materials chosen was on Unit 1 which focused on the basic information of terminals in Tanjung Perak area, Surabaya as the smallest entity in operation of the corporate. Unit One and 
Session One was chosen as this first meeting would be a very critical meeting to start the program, including to condition the learners to the learning activity, especially on a specific program about the port. Building atmosphere and energy towards the class would be the critical point to attract the learners to attend to the next meeting, as majority of them would not join the program voluntarily but were assigned by the corporate.

This group was assumed as similar to those with non-operation background, therefore their knowledge on the operation procedure was minimum. The duration of the try out was 90 minutes. After the learners entered the class, they were seated on the designated area. They were equipped with stationary and laptop and they used their own phones with voice recorder installed prior to the class.

In the beginning, they were put into a group of three. It was actually designed for a pairwork, but one learner was absent so the researcher modified it into a group of three. The teacher introduced herself as it was the first meeting, explaining about the program and the objective of the meeting today relating to what they did in real life event.

One text about the description of terminals in Tanjung Perak is prepared, printed and attached on the wall. The same text, but some words are deleted to leave some blanks, is prepared on the other side of the room for the rest of the team members to fill. One learner is assigned to dictate the text to the members, and the members should fill in the blanks. After two sentences, the teacher asks the learner to switch with the second member and it goes the same with the third member as a cycle until the end of the text. The total duration of the activity is 20 minutes, including checking the answer. The teacher assists the learners for the difficult vocabulary or the challenge they experience during the activity.

The teacher then switched to the second materials about the description of the other terminals in PT Pelindo III areas. The learning material was taken from the official company profile which provided the basic information of each terminal. Each learner was assigned as the GM 
of certain terminal, and the others should make minimum 6 questions related to the terminal. They took turn for all terminals. In total, one learner had 12 pieces of information from two terminals. During the interview, they made a note of the information, however, the teacher encouraged them to write down only the important information instead of the complete sentences to save time. By the end of the activity, they reported their information, recorded their voice in their own phone and sent it by WhattApp to the teacher.

The teacher then reviewed the materials that day and asked for any difficult vocabulary, and described each vocabulary. After that, the teacher explained to them about the activity for the next meeting and the things they must prepare for presenting the next topic on terminal formal presentation with PowerPoint visual aid. The teacher explained that the slides must consist of the size, location, performances, issues, and suggestions. Time was given for those who asked questions.

\section{Evaluation}

During the study, the following issues were found:

\section{Analysis}

The needs analysis involving the hirer or the head of training departments could answer basic information about the potential learners, however, they had a very limited information about the operation activity which closely related to the design of the syllabus. However, the discussion with operation department could give comprehensive knowledge on the materials. In addition, the materials given by the corporate communication department were also very helpful in developing the materials. Some materials were in Bahasa Indonesia, so the researcher had to modify them in order to meet the desired target of the materials.

Furthermore, the questionnaires distributed to the potential learners were initially 60 questionnaires, but only eight people responded 
during the time given. The rest did not respond for unknown reasons. It might have contributed into a more comprehensive analysis if all potential learners had responded but it was indeed beyond the researcher's control to get them to participate.

\section{Designing}

The process of designing the syllabus underwent several revisions to meet the final version to make the objective and the language focus suitable with the needs. To design this syllabus as a task-based syllabus (Khranke, 1987), the first process was arranging the topic based on the complexity scope, from the smallest to the biggest as stated in the developing stage above.

The second phase was to design the objective of each topic. After consulting with an expert, it was suggested that the objective and the outcome were separated to give a clear direction for both the teacher and the learners. The global objective then cascaded into a very detailed outcome which included audience, behavior, condition, and degree.

Language function was the next item to design, that each topic consisted of specific target of language function that the learners had to master. Some topics had similar language function as in asking informational question. They were frequently emphasized to give the learners the ability and the confidence in a two-way communication as well as being critical. The second most frequent language function was describing and it is demonstrated in various activities that is in describing procedures and business presentation. It is in response to the specific request of the hirer as the nature of the learners' work requires business presentation.

The fourth stage to design was the learning model which focuses on the learner-centered ones in various activities. In order to produce more sentences, the learners need to practice more, therefore pair or group work are employed. In some meetings, formal presentation followed by 
discussion sessions are employed to promote active engagement among learners.

The next stage was the selection of media used in class. In accordance to their corporate policy of using zero paper, digital and online media are advised. Tablet, laptop, and cellular phones are the ideal means of teaching learning activities. The materials are distributed in PDF version or by link and the learners are accessing through their own gadget.

This program employs portfolio in the assessment model as every production counts. Besides, the learners are always able to track their production progress, which is considered essential for busy adult learners to keep their motivation. The percentage of the assessment depends on the complexity of the task or the activity. Naturally, the tasks worth as the midterm and the final contributes more percentage, $20 \%$ each while others are worth $10 \%$ for each topic.

The last topic about field trip using the corporate mini-cruise was excluded from the final syllabus design based on the hirer's request. She informed that the availability of the mini-cruise was unpredictable as they were also chartered for public use. Besides, the coordination for the cruise use would involve the subsidiary of the company with a relatively complex bureaucracy. 
Those steps are summarized into

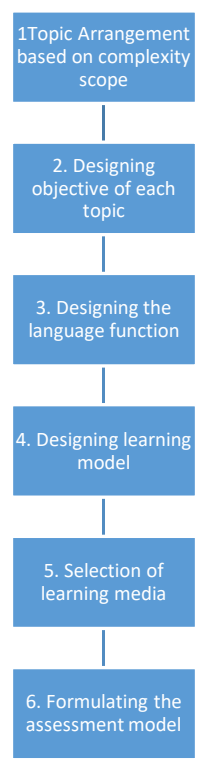

Figure 2. Syllabus Design Stage

\section{Developing}

The development process took the longest process among all as it combined different resources. The interview result gave a comprehensive overview about what were needed in English communication with port operation perspective. As the interview was accompanied by a site visit, the researcher was enriched with observation of different activities of the port. During the reading of the corporate website and the guidebook, the researcher could relate the information of the text with the observation before, which significantly enhanced the understanding of the business itself. There were one official websites and a series of corporate guidebooks consisting of ten books discussing the general information about port business. Powerpoint files about the overview of the business were also available for the study. The files were initially created to be presented for public context; therefore, they were invaluable resources for those who are not familiar with the port business. 
Consulting with the expert was one strategy employed when there were incomprehensible terminologies, besides consulting to technical dictionary. Corporate annual report was also studied to see the overview of corporate performances and to obtain the English version of several port terminologies.

\section{Implementing}

From the try out, it was found that specific terminologies about port must be the utmost focus for the repetitive use in order to familiarize the learners as they are used during the whole program. The terminologies should be reviewed in each chapter.

In the area of teaching learning method, grouping played an important part in the learning pace. Pair work was considered the most ideal method as the waiting time for the turn would be minimum and each learner could produce an optimal number of sentences each meeting. In addition, the portion of the materials compared to the allotted time was considered sufficient.

As this program commits to produce one product per meeting, the feasible products for the speaking activities were voice recordings. A Learning Management System (LMS) is strongly suggested to be used in managing many files of the learners' recording. However, a special format of file naming should be taken into account and the researcher suggested to use the topic title_name of the learner and post it into specific folder in the LMS. In case there are problems with the LMS, sending them by email will be very helpful for the teacher to compile their files later. Additional identification is that the learner must mention their names and division in the beginning of every recording.

In the discussion of the language function, it is important for the teacher to always introduce specific patterns or utterances in the beginning of the meeting, and repeat them in the summary by the end of the meeting. Although this try-out showed that the participants were less accurate in 
using the auxiliaries during making question in the second activities, when the teacher reminded them, they could relate and revised their sentences. Only one participant was not able to repeat the revision of the teacher.

Based on the interview with the learners after the try out sessions, they stated that the materials and the methods were interesting, as they had no experience of having a class full of speaking activities. It was difficult for them in the beginning of the class to speak up, but during the second activity, they started to communicate actively using full English with their friends. The participants admitted that the vocabulary related to port were relatively difficult and they needed to repeat them over and over again to be familiar with. During the recording sessions, the size of the room influenced the clarity of the voice, which later will cause difficulty to the teacher for the replay in the scoring process. However, the size of the room and the position of each learner mattered. It is suggested that the learners put the phone microphone at about 1 centimeter distance from their mouth and have minimum one meter distance with the other friend.

The self, pair and teacher assessment on their production was scheduled on the second meeting to prevent learners' confusion of having too much information on the first meeting.

\section{Conclusions}

The syllabus and materials prepared for the port business employees cater to their need in using the target language communicatively through activities which enable them to speak about their business in interactive ways. It was proven by the try out result which showed that the learners enjoyed the activity while they could produce many sentences during class. Therefore this syllabus and materials are suitable to be used in the context of port business for the employees with limited time to learn.

Further study on materials development is suggested in other fields in maritime and logistic business such as the transportation, the maritime safety and possibly to expand to the broader profession. It is 
necessary to create materials suited with the professionals' limited time and energy to learn English; therefore the best formula should be further investigated in more advanced research studies.

\section{References}

Aldobie, N. (2015). ADDIE Model. American International Journal of Contemporary Research, 68-72.

Bocanegra-Valle, A. (2010). Global Markets, Global Challenges: The Position of Maritime English in Today's Shipping Industry. English in the European context: The EHEA challenge, 151-174.

Brown, H. D. (2000). Principles of language learning and teaching.

Cunningsworth, A. (1995). Choosing Your Coursebook. Heinemann.

Damron, D., Damron, J., \& Bush, M. (2006). A Template for Development of Special-Purpose Language Courses. The Journal of Language for International Business, 17(2), 82.

Ellis, R. (1997). The Empirical Evaluation of Language Teaching Materials. ELT journal, 51(1), 36-42.

Gabrielli, A. (2016). Standardising Maritime English Training and Assessment through International Coordination of Content-Based Instruction. Scripta Manent, 10(2), 52-62.

Graves, K. (2008). The Language Curriculum: A Social Contextual Perspective. Language Teaching, 41(2), 147-181.

Hutchinson, T., and A. Waters, 1987. English for Specific Purposes: A Learning- Centered Approach, Cambridge University Press. Cambridge.

Jordan, R. R. (2011). English for Academic Purposes. United Kingdom: University Press, Cambridge. 
Krahnke, K. (1987). Approaches to Syllabus Design for Foreign Language Teaching. Language in Education: Theory and Practice, No. 67. Prentice-Hall, Inc., Book Distribution Center, Route 59 at Brook Mill Drive, West Nyack, NY 10994.Tomlinson, B. (2008). English Language Teaching Materials. London: Continuum.

Nunan, D. (1988). Principles for Designing Language Teaching Materials. Guidelines: A periodical for classroom language teachers, 10(2), $1-24$.

Richards, J. C., \& Lockhart, C. (1994). Reflective teaching in second language classrooms. Cambridge University Press.

Tahir, A. (2011). Learning Needs-A Neglected Terrain: Implications of Need Hierarchy Theory for ESP Needs Analysis. English for Specific Purposes World, 33(11).

Tomlinson, B. (Ed.). (2011). Materials Development in Language Teaching. Cambridge University Press.

Tomlinson, B. 1998. In Tomlinson, B. (Ed.), Materials Development in Language Teaching. Cambridge: Cambridge University Press. 